\title{
Geriatrik kalça kırığı tedavisinde mediko-legal sorunla karşılaşmamak için nelere dikkat edilmeli?
}

\section{What should be considered in order not to encounter medico-legal problems in treatment of geriatric hip fractures?}

\author{
Serdar Şirazi ${ }^{1,2}$, Ahmet Murat Bülbül ${ }^{3}$ \\ ${ }^{1}$ Özel Avcılar Anadolu Hastanesi, Ortopedi ve Travmatoloji Kliniği, İstanbul \\ ${ }^{2} S$ Şahin Avukatlık Bürosu - Akademi Arabuluculuk ve Tahkim Merkezi, İstanbul \\ ${ }^{3}$ Sağlık Hukuku Bilimi Uzmanı; İstanbul Medipol Üniversitesi Ortopedi ve Travmatoloji Ana Bilim Dalı, İstanbul
}

\begin{abstract}
Geriatrik yaş grubunda yani 65 yaş ve üzerindeki hasta grubunda özellikle travmatik kalça kırı̆̆ı görülme sıklığı gerek genel nüfusun artmasına gerekse geriatrik yaş grubu popülasyonunun artmasına bağlı olarak son dönemlerde daha fazla karşılaşılır olmuştur. Bu hastalarda düşme, beslenme sorunları, bası yaraları, osteoporoz, demans ve deliryum tabloları oldukça sık görülmekte, bu da travmatik kalça kırıklarının gelişmesine, hekimin hasta ile olan iletişiminde problemler yaşanmasına neden olmaktadır. Kalça kırıklı hastaların ameliyat hazırlıklarında konsültasyonlarının yanında aslında en az bunun kadar önemli olan hastayı bilgilendirme ve yapılacak işlem için onamının alınması hukuki olarak da ayrıca öneme sahip olmaktadır. Makalemizde bu konuda ortopedi ve travmatoloji uzmanlarının hangi durumda nasıl hareket etmesi gerektiği yönünde tıbbi ve hukuki bilgilerin verilmesi hedeflenmiştir.
\end{abstract}

Anahtar sözcülkler: kalça kırığı; aydınlatılmış onam; bilgilendirilmiş rıza; sağlık hukuku; tıp hukuku
The incidence of traumatic hip fractures in the geriatric age group, i.e. the patient group aged 65 and over, has recently been more common due to increase in both general and geriatric populations. Falls, nutritional problems, pressure sores, osteoporosis, dementia and delirium are quite common in these patients, leading to the development of traumatic hip fractures and problems in the communication between the physician and the patient. In addition to the consultations of patients with hip fractures during preoperative preparation, it is also legally as important to inform the patient and obtain consent for the procedure. In our article, it is aimed to provide medical and legal information on how orthopedics and traumatology specialists should act depending on the situation.

Key words: hip fracture; informed consent; health law; medical law

bilinirken, 2025 yılında 840 milyona ulaşacağı ve yaşlıların \%70'inin gelişmekte olan ülkelerde özellikle de Asya kıtasında yaşayacağı öngörülmektedir. ${ }^{[3]}$

Türkiye İstatistik Kurumu'nun (TÜiK) verilerine göre Türkiye'de 2013-2015 döneminde doğuşta beklenen yaşam süresi 78 yıl, 2017-2019 döneminde 78,6 yıl olarak tespit edilmiştir. ${ }^{[4]}$ Yine Türkiye'de 65 yaş ve üzeri yaştaki nüfus 2014 yılında 6 milyon 192 bin 962 kişi iken, son beş yılda \%21,9 oranında artarak 2019 yılında 7 milyon 550 bin 727 kişi olarak saptanmıştır. Yaşlı nüfusun toplam nüfus içindeki oranı 2014 yılında \%8 iken, 2019 yılında \%9,1'e yükselmiştir. ${ }^{[5]}$ Bu oranın \%10'u geçmesi nüfusun yaşlanmasının bir göstergesi

\footnotetext{
- Illetişim adresi: Uzm. Dr. Serdar Şirazi, Florya Plaza, Şenlikköy Mah., Eski Halkalı Cad., No: 3, K: 2, D: 25 B. Florya, Bakırköy, İstanbul Tel: 0536 - 6811187 e-posta: drserdarsirazi@yahoo.com

- Geliş tarihi: 30 Aralık $2020 \quad$ Kabul tarihi: 11 Ocak 2021
}

ORCID iD: Serdar Şirazi, 0000-0002-2155-1894 • Ahmet Murat Bülbül, 0000-0002-0692-4760 
olarak kabul edilmektedir. Türkiye'de yaşı nüfus diğer yaş gruplarındaki nüfusa göre daha yüksek hız ile artış göstermektedir. Dolayısıyla, mevcut demografik yapılar önümüzdeki dönemde ortopedi ve travmatoloji pratiğinde daha fazla geriatrik yaş grubu ile karşılaşılacağını ortaya koymaktadır.

Geriatrik yaş grubunda yani 65 yaş ve üzerindeki hasta grubunda özellikle travmatik kalça kırığı görülme sıklığı gerek nüfusun artması gerek geriatrik yaş grubu popülasyonunun artmasına bağlı olarak son dönemlerde daha fazla karşılaşılır olmuştur.

Geriatrik yaş grubundaki hastalarda düşme, beslenme sorunları, bası yaraları, osteoporoz, demans ve deliryum tabloları oldukça sık görülmektedir. Bu da travmatik kalça kırıklarının gelişmesine, hekimin hasta ile olan iletişiminin çok sağlıklı olamamasına ve ameliyat sonrası bakımlarda sıkıntılar yaşanmasına sebebiyet vererek, ortopedi ve travmatoloji uzmanlarının bu konuya ayıracakları zamanın ve yaşanabilecek problemlerin daha fazla olması sonucunu doğurmaktadır.

Türkiye'de yaşılıarda sıklıkla görülen kronik hastalıklar sıralamasında hipertansiyon $\% 30,7$, orteoartrit $\% 13,7$, kronik kalp yetmezliği \%13,7, diyabetes mellitus $\% 10,2$, koroner arter hastalığı $\% 9,8$ ve osteoporoz $\% 8,2$ olarak saptanmıştır. ${ }^{[6]}$ Osteoartrit ve osteoporoz ortopedi ve travmatoloji hekiminin pratiğinde karşılaşacağı hastalıkların başında gelmektedir.

Deliryum tablosu, kalça kırıklarından sonra \%28 ile \%61 oranında görülmektedir. ${ }^{[7]} \mathrm{Bu}$ da ameliyat sonrası hasta bakımlarında karşılaşılma potansiyeli yüksek problemler olduğunu göstermektedir.

Söz konusu travmatik kalça kırıkları hastalarının artması beraberinde hukuki problemleri de getirmektedir. Özellikle bu yaş grubundaki hastalar ile iletişim kurma güçlügü, hastaların bilişsel fonksiyonlarının yavaşlamış olması, yakınlarından uzak bir yerde yaşamaları ve vasilerinin olmaması sorunun daha da aşikâr hale gelmesine neden olmaktadır.

Kalça kırıkları sonrası mortalite ve morbidite oranı cerrahinin yapılacağı zamana bağı olarak da değişmektedir. Özellikle kırıktan 48 saatten sonra yapılan cerrahi girişimlerden sonra mortalite açısından anlamlı bir artış olduğu saptanmıştır. ${ }^{\left[{ }^{[8}\right.}$ Hastaların hastaneye yatırıldıktan sonra ameliyat hazırlıkları hastanın ek hastalıklarının olup olmamasına bağlı olarak uzun sürebilmekte bu da yapılacak cerrahinin tehirli olmasına neden olabilmektedir.

Kalça kırıkı hastaların ameliyat hazırlıklarında, konsültasyonlarının yanında aslında en az bunun kadar önemli olan hastayı bilgilendirme ve yapılacak işlem için onamının alınması hukuki olarak da ayrıca öneme sahiptir. Geriatrik hastalardaki iletişim problemleri ortopedi ve travmatoloji uzmanı - hasta - hasta yakını arasındaki ilişkide sıkıntılar yaşanmasına neden olmaktadır.

\section{ETiK DEĞERLENDIRME}

Hipokratçı anlayışta sağıı çalışanı yalnız hastanın esenliği için çalışmakta ve yarara ilişkin nesnel veya öznel değerlendirmelerde bulunmaktaydı. Yani hasta için yarara ilişkin yargılardan; ilgili hekimin görüşü öznel değerlendirme yapısını oluştururken, kişiden bağımsız olarak doğru kabul edilen değerlendirmeler nesnel yapidadır. ${ }^{[9]}$

Tıp etiğinde yararlı olma, zarar vermeme ve özerkliğe saygı ilkeleri yer almaktadır. Bu ilkeler kişinin kendi sağlık durumu hakkında bilgi sahibi olma hakkını, yapılacak müdahale konusunda kendi kararını verme hakkını doğurmakta, bu da aydınlatılmış onam kavramını doğurmaktadır.

Daha önceleri tıbbın yaşam kurtarıcı etkisi ön plandayken günümüzde bununla birlikte hayat kalitesini arttırma etkisi de ön plana çıkmaktadır. Yani daha önceleri kalça kırı̆ı hastalarının mortalitesini azaltmak esas hedef iken, son dönemlerde mortalitenin azaltılmasıyla birlikte ağrısız ve erken dönem hareketlenme hedeflenmekte, konforlu bir hayat kalitesi sağlanmaya çalışılmakta ve hastalar tarafından da beklenmektedir.

Hekim tarafından belirlenen yarar kavramı her zaman her koşulda hasta açısından tam olarak geçerli olmayabilir. Kalça kırığı olan kişi ameliyat olmadığı durumda yürüyemeyeceğini hatta yatakta bile dönmekte zorluk çekeceğini bilmesine rağmen, yapılacak cerrahi girişimde vefat etme riskini almak istemeyebilir. Yani hasta bazında yarar tamamen hastanın öznel değerlendirilmesidir.

Tıbbi esenliğin hastanın bütüncül esenliğine devşirilmesi güncel tıp uygulamasında bulunmaktadır. Tıbbi esenliğin artmasını sağlamak (kalça kırığına yönelik cerrahi yapmak) veya bu yolda adım atmak hastanın bütüncül esenliğinde ciddi kayıplara (komplikasyonlara bağlı revizyon cerrahi gereksinimi) hatta hastanın kaybına neden olabilmektedir. Yani, esenlik bir değer yargisıdır.

Hekimin bireysel ya da heyet değerlendirmesi yerine hastanın kendi kişisel değerlendirilmesini temel almak güncel bir yaklaşım haline gelmektedir. Hasta için yarar-zarar oranı farklı olabilmektedir ve yarar kişiye özgüdür. Dolayısıyla, paternalist yapı olan hipokratçı yaklaşım yerini hasta esenliğine, hastanın tanı ve tedavi sürecine aktif olarak katılmasını sağlamıştır. Tüm bunlar güncel tıp uygulamasında hekimin yapılacak tıbbi müdahalede hastasını aydınlatarak hastanın onamını alması gerekliliği sonucunu doğurmuştur. 
Tıbbi müdahalenin hukuka ve kişilik hakkına aykırı müdahale olarak teşkil etmemesi için;

- Müdahalenin tedavi amacıyla yapılması

- Müdahaleyi yapacak kişinin bu konuda yetkili olması

- Tıp biliminin kurallarına uygun olarak yapılması

- Hastanın rıza göstermiş olması gerekmektedir.

Hastanın rıza göstermesi için hastalığının tanısını bilmesi gerekmekte, tedavi şeklinin varsa alternatifleriyle kendisine sunularak bir değerlendirmede bulunarak karar vermesi ile olabilecektir.

Aydınlatma ve onamını alma aslında insan hakları ile doğrudan ilgili olup anayasal olarak da güvence altına alınmıştır. Anayasa'da "Tıbbi zorunluluklar ve kanunda yazılı haller dışında, kişinin vücut bütünlüğüne dokunulamaz; rızası olmadan bilimsel ve tıbbi deneylere tabi tutulamaz" ibaresi yer almaktadır. ${ }^{[10]}$ Avrupa Insan Hakları Sözleşmesi'nde hak ve özgürlükler başlığında herkesin yaşam hakkının yasayla korunacağına dair madde yer almaktadır. ${ }^{[11]}$

\section{HEKIM-HASTA íLişKisi}

Mevcut Türk hukuk sisteminde hekim hasta ilişkisini iki taraflı hukuki işlem olarak yani sözleşme olarak nitelendirebiliriz. İki tarafın karşııklı ve birbirine uygun irade açıklamalarının gerekli olduğu bir işlemdir. Vekalet sözleşmesi kabul edilen bu ilişkide vekil (hekim), hastanın zarar görmemesi için, mesleki tüm şartları yerine getirmeli, hastanın durumunu tıbbi açıdan zamanında ve gecikmeksizin saptayıp somut durumun gerektirdiği önlemleri eksiksiz biçimde almalı, uygun tedaviyi de yine gecikmeden belirleyip uygulamalı, bunda da kıstas olarak da basiretli bir vekilin (hekimin) göstermesi gereken davranışın esas alınması gerektiği yüksek mahkeme kararlarında sıklıkla yer almaktadır. ${ }^{[12]}$

Burada karşııılı iradelerinin belirtilmesi hastanın da yapılacak tedaviyi istemesini beyan etmesiyle gerçekleşebilecektir. Bu da hukuki işlemin şekil şartı olarak nitelendirilebilecektir. Ayrıca bunun için kişinin fiil ehliyetinin olması gerekmektedir. Fiil ehliyeti: bir kişinin kendi fiiliyle hak edinebilmesi, borç altına girebilmesi ve haksız fiillerden sorumlu tutulabilmesi için gerekli olan ehliyettir. ${ }^{[13]}$ Türk Medeni Kanunu'na göre ayırt etme gücüne sahip ve kısıtlı olmayan her ergin kişinin fiil ehliyeti vardır. ${ }^{[14]}$ Aynı kanunda ayırt etme gücü bulunmayanların, küçüklerin ve kısıtlıların fiil ehliyeti yoktur denmektedir. ${ }^{[14]}$ Dolayısıyla, bir hastanın yapılacak müdahaleye onay vermesi için fiil ehliyetinin olması gerekmektedir. Yaşlı hastaların ayırt etme gücü ve kısıtlı olup olmaması da söz konusu yazının ana konusunu teşkil etmektedir.
Ayırt etme gücü bir kişinin akla uygun biçimde davranması, fiillerinin sebep ve sonuçlarını kavrayabilme yeteneği olarak açıklanmaktadır. ${ }^{[13]}$ Ayırt etme gücünü ortadan kaldıran sebepler yaş küçüklüğü, akıl hastalığı, akıl zayıflığı ve sarhoşluk olarak sayılmaktadır.

Kısıtlı olmamak da fiil ehliyeti açısından gerekli bir kriterdir. Türk Medeni Kanunu'nda kısıtlama sebepleri olarak akıl hastalığı veya akıl zayıflığı, savurganlık, alkol veya uyuşturucu madde bağımlılığı kötü yaşama tarzı, kötü yönetim olarak sayılmıştır. ${ }^{[14]}$

Tüm bunların ışığında fiil ehliyetlinin kişide bulunup bulunmamasına göre ehliyetliler ve ehliyetsizler olmak üzere ikiye ayrılmaktadır.

Ehliyetliler;

- Tam ehliyetliler (Ayırt etme gücüne sahip ve kısıtlı olmayan ergin kişilerdir.)

- Sınırlı ehliyetliler (Fiil ehliyetleri sınırlanmış ve kendilerine yasal danışman atanmış kişilerdir.)

Ehliyetsizler;

- Tam ehliyetsizler (Ayırt etme gücünden yoksun olan kişilerdir. Fiil ehliyetleri yoktur. Yaptıkları hukuki işlem kesin hükümsüzdür. Ancak yasal temsilcisi tarafından işlem yapılabilir.)

- Sınırlı ehliyetsizler (Ayırt etme gücüne sahip küçükler ile ayırt etme gücüne sahip kısıtlılardır.) (Yasal temsilcilerinin rızası ile geçerli olarak hukuki işlemleri yapabilirler.) (Kişiye sıkı sıkıya bağlı haklarını kullanmada yasal temsilcilerinin rızasına ihtiyaç yoktur.)

olarak sınıflandırılırlar. Dolayısıyla, sınırlı ehliyetliler ve ehliyetsizlerin yasal temsilcileri bu konuda yetkilidir. ${ }^{[15]}$

Dolayısıyla, söz konusu ayırımda ayırt etme gücü olmayan ve kısıtlı olan kişilerin yasal temsilcileri aracıIığıyla yapılacak tıbbi müdahale konusunda onamının olması sonucunu doğurmaktadır.

\section{Aydınlatma-Bilgilendirme}

Aydınlatılmış onam özerkliğe önem veren bir kuramdır. Hekimin hastasına tıbbi açıdan faydalı olmadığını düşündüğü bilgileri bile hastaya bildirmesinin gerekliliği bunun bir parçasıdır. Aydınlatma ve onay verme ile kişinin kendi kaderini kendisinin belirleme durumu gelişmiş ve bu Bali Bildirgesi'nde yer almıştır. ${ }^{[16]}$

Aydınlatma, yapılacak girişimin her şeyini anlatmak değildir. Zaten bu teoride ve pratikte imkânsızdır. Yapılması gereken yeterince bilgilendirme yapılmasıdır. Burada üç ölçüt bulunmaktadır.

- Meslektaş ölçütü

- Makul kişi ölçütü

• Öznel ölçüt 
Meslektaş ölçütü diğer meslektaşların hastaya hangi bilgileri veriyorsa, ilgili hekimin de benzer bilgileri açıklamasını, makul kişi ölçütü makul bir hastanın bilmek isteyeceği ya da önemli bulabileceği her türlü bilgiyi, öznel ölçüt ise verilecek bilginin hastanın yaşantısı ve hastanın çıkarları ile uyuşması ölçüsünü gösterir.

Hasta Hakları Yönetmeliği'nde bilgilendirmenin kapsamı detaylı olarak verilmiştir. Bilgilendirme "Yapılması planlanan her türlü tıbbi müdahale öncesinde müdahaleyi gerçekleştirecek sağılı meslek mensubu tarafindan kişiye gerekli bilginin verilmesi" olarak tanımlanmıştır. ${ }^{[17]}$

Bilgilendirmede;

- Hastalığın muhtemel sebepleri ve nasıl seyredeceği,

- Tıbbi müdahalenin kim tarafından nerede, ne şekilde ve nasıl yapılacağı ile tahmini süresi,

- Diğer tanı ve tedavi seçenekleri ve bu seçeneklerin getireceği fayda ve riskler ile hastanın sağlığı üzerindeki muhtemel etkileri,

- Muhtemel komplikasyonları,

- Reddetme durumunda ortaya çıkabilecek muhtemel fayda ve riskleri,

- Kullanılacak ilaçların önemli özellikleri,

- Sağlığı için kritik olan yaşam tarzı önerileri,

- Gerektiğinde aynı konuda tıbbî yardıma nasıl ulaşabileceği yer almalıdır. ${ }^{[17]}$

Verilecek bilginin mümkün olduğunca sade, tereddüt ve şüpheye yervermeden, hastanın sosyal ve kültürel düzeyine uygun olarak anlayabileceği şekilde müdahaleyi gerçekleştirecek sağlık mensubu tarafından sözlü olarak yapılması gerektiği belirtilmektedir. Bilgilendirmeyi yapacak kişi ile tıbbi müdahaleyi yapacak sağlık meslek mensubunun farklı olmasını zorunlu kılan durumlarda, bu duruma ilişkin hastaya açılama yapılmak suretiyle bilgilendirme yeterliliğine sahip başka bir sağlık meslek mensubu tarafından bilgilendirmenin yapılabileceği yine aynı yönetmelikte yer almaktadır.

Bu durum eğitim ve araştırma hastanelerinde veya üniversite hastanelerinde oldukça sık karşılaşılan bir durumdur. Kalça kırığı nedeniyle acile başvuran hastayı acilde bulunan ortopedi ve travmatoloji hekimi görmekte, ilgili hekim hastayı ameliyat açısından bilgilendirmekte ancak ameliyathane ekibi tarafindan ameliyat edilmektedir. Gerek yoğunluğun gerekse eğitimin bir parçası olan söz konusu durumda acilde karşılayan hekimin cerrahi müdahaleyi ameliyathanede bulunan başka bir ekip veya hekim tarafindan yapılacağı konusunda da bilgilendirme yapması gerekmektedir. Bilgilendirmede hekim hastasını, hastanın sağlık durumu ve konulan tanı, önerilen tedavi yönteminin türü, başarı şansı ve süresi, tedavi yönteminin hastanın sağlığı için taşıdığı riskler, verilen ilaçların kullanılışı ve olası yan etkileri, hastanın önerilen tedaviyi kabul etmemesi durumunda hastalığın yaratacağı sonuçlar, olası tedavi seçenekleri ve riskleri konularında aydınlatır. Yapılacak aydınlatma hastanın kültürel, toplumsal ve ruhsal durumuna özen gösteren bir uygunlukta olmalıdır. Bilgiler hasta tarafından anlaşılabilecek biçimde verilmelidir. Hastanın dışında bilgilendirilecek kişileri, yine hastanın kendisi belirleyecektir. ${ }^{[18]}$

Bilgilendirmenin bizzat hastanın kendisine yapılması esastır. Ancak hastanın kendisi yerine bir başkasının bilgilendirilmesini talep etmesi halinde, bu talep kişinin imzası ile yazılı olarak kayıt altına alınmak kaydıyla sadece bilgilendirilmesi istenilen kişilere bilgi verilir. ${ }^{[17]}$ Yargıtay 13. Hukuk Dairesi'nin vermiş olduğu bir kararda davacının eşine yapılan aydınlatmanın geçerli olmadığı vurgulanmıştır. ${ }^{[19]}$

Hasta durumu ile ilgili bilgi verilmemesini isteyebilir. Kişi, sağlık durumu hakkında kendisinin, yakınlarının ya da hiç kimsenin bilgilendirilmemesini isteyebilir. Bu durumda kişinin kararı yazılı olarak alınır. Hasta bilgi verilmemesi talebini istediği zaman değiştirebilir ve bilgi verilmesini talep edebilir. ${ }^{[17]}$

6023 sayılı Türk Tabipleri Birliği Kanunu'nun 59/g maddesine dayanılarak hazırlanan Hekimlik Meslek Etik Kuralları'nda hasta hastalığı konusunda bilgilendirilmek istemediğini belirtmişse, hekimin bilgi vermesinin gerekmeyeceği, ailenin haberdar edilmesinin hastayla görüş birliğine varılarak yapılması gerektiği, bilinci kapalı hastalar için, yakınlarının bilgilendirilip bilgilendirilmemesine hekimin karar vereceği belirtilmektedir. ${ }^{[18]}$ Avrupa İnsan Hakları Mahkemesi'ne göre taraf devletle, uygulanması planlanan tıbbi işlemin öngörülebilir sonuçları hakkında doktorların hastalara önceden bilgi vermelerini sağlayacak gerekli düzenleyici tedbirleri almak zorunda olduğunu, bunun bir sonucu olarak hastanın önceden bilgilendirilmesinin söz konusu olmadan öngörülebilir nitelikte bir riskin ortaya çıkması durumunda ilgili devletin hastaya bilgi verilmemesinden sorumlu tutulabileceğini belirtmiştir. ${ }^{[20]}$

Avrupa Hasta Haklarının Geliştirilmesi Bildirgesi'nde (Amsterdam Bildirgesi) hastaların durumları ile ilgili tıbbi gerçekleri, önerilen tıbbi girişimleri ve her bir girişimin potansiyel risk veya yararlarını, önerilen girişimlerin alternatiflerini, tedavisiz kalmanın sonucunu, tanı, prognoz ve tedavinin gidişi konularını içerecek şekilde sağlık durumları konusunda tam olarak bilgilenme hakkına sahip olduğu vurgulanmaktadır. Bilgilendirme, yalnızca bilgi vermemenin hasta üzerinde açık ve olumlu bir etkisinin olacağına inanmak gibi geçerli bir nedenin olduğu zamanlarda kısıtlanabilece$\breve{g i}$, verilen bilginin hastanın anlama kapasitesine uygun 
bir yolla ve yabancı teknik terminoloji en aza indirerek iletilmesi gerektiği, hastanın ortak dil konuşmaması durumunda çeviri yapılabileceği ve hastaların kesin olarak belirttikleri takdirde bilgilendirilmeme hakkına sahip oldukları vurgulanmıştır. [21]

Yine Bali Bildirgesi'nde hastanın kendisi ile ilgili tıbbi gerçekler dâhil olmak üzere sağlık durumu konusunda tam olarak bilgilendirilme ve kendisi hakkındaki tıbbi kayıtlara ulaşma hakkına sahip olduğu belirtilmektedir. Bunun istisnası olarak da eğer hastaya verilecek bilginin onun yaşamı veya sağlığı üzerinde ciddi zararı olacağına inanılıyorsa hastanın bilgilendirilmeyebilece$\breve{g i}$, bilgilendirmenin yerel kültüre uygun olarak ve hastanın anlayabileceği şekilde yapılması gerektiği ve hastaların kendileri yerine kimin bilgilendirileceğini seçme hakkına sahip oldukları belirtilmektedir. ${ }^{[16]}$

Yargıtay kararında aydınlatma yükümlülügünün yerine getirilmemiş oluşunun, yapılan müdahaleyi hukuka aykırı hale getirdiğinden manevi tazminat dışında maddi tazminattan da sorumlu olunacağına dair kararı bulunmaktadır. ${ }^{[22]}$

Kalça kırıklarında hastaya osteosentez planlanıyorsa kaynamama, implant yetmezliği, yanlış kaynama, psödoartroz, enfeksiyon, osteomiyelit hatta nadir de olsa ampütasyon yapılabileceği, bunların her türlü özene rağmen meydana gelebileceği ve bu durumlarda yapılması gereken ek cerrahi veya cerrahi dışı işlemlerin olası olduğu bilgisi verilmelidir. Hastaya artroplasti planlanıyorsa ameliyat öncesi damar-sinir yaralanmasının olabileceği, çıkık geliş̧ebileceği, protezin kırılabileceği, ilerleyen dönemlerde protezin değişmesinin gerekebileceği özellikle verilmesi gereken bilgiler arasında yer almaktadır.

\section{RIZA-ONAM}

Rıza; kişinin tıbbi müdahaleyi serbest iradesiyle ve bilgilendirilmiş olarak kabul etmesi olarak tanımlanmıştır. ${ }^{[17]}$ Sağlıkla ilgili her türlü girişim, kişinin özgür ve aydınlatılmış onamı ile yapılabilir. Hekimlik meslek etik kurallarında "Alınan onam, baskı, tehdit, eksik aydınlatma ya da kandırma yoluyla alındıysa geçersizdir. Acil durumlar ile hastanın reşit olmaması veya bilincinin kapalı olduğu ya da karar veremeyeceği durumlarda yasal temsilcisinin izni alınır. Hekim temsilcinin izin vermemesinin kötü niyete dayandığını düşünüyor ve bu durum hastanın yaşamını tehdit ediyorsa, durumu adli mercilere bildirilerek izin alınmalıdır. Bu konuda nöbetçi sulh hukuk mahkemelerine başvurulduğunda kısa sürede çözüm gerçekleşebilecektir. Bunun mümkün olmaması durumunda, hekim başka bir meslektaşına danışmaya çalışır ya da yalnızca yaşamı kurtarmaya yönelik girişimlerde bulunur. Acil durumlarda müdahale etmek hekimin takdirindedir. Tedavisi yasalarla zorunlu kılınan hastalıklar toplum sağglı̆ıını tehdit ettiği için hasta veya yasal temsilcisinin aydınlatılmıs onamı alınmasa da gerekli tedavi yapılır. Hasta vermiş olduğu aydınlatılmış onamı dilediği zaman geri alabilir" ifadesi mevcuttur. ${ }^{[18]}$

Tababet ve Şuabatı Sanatlarının Tarzı İcrasına Dair Kanun'un 70. maddesinde "Tabiplerin yapacakları her çeşit ameliyatta hastanın, hasta kısıtlı ise vasisinin onayını almaları gerektiği, büyük ameliyatlar için bunun yazılı olması gerektiği, vasisinin olmadığı veya bulunmadığı veya ameliyat olacak kişinin kendini ifade edemediği durumlarda onamın şart olmadığı belirtilmektedir. ${ }^{[15]}$ Dolayısıyla, rıza şartı tedavinin ön koşulu olarak benimsenmiştir.

Hasta Hakları Yönetmeliği'nde kanunda gösterilen istisnalar hariç olmak üzere, kimsenin rızası olmaksızın ve verdiği rızaya uygun olmayan bir şekilde tıbbi ameliyeye tabi tutulamayacağı söylenmektedir. ${ }^{[17]}$

Aynı yönetmelikte rızanın alınırken hastanın veya kanuni temsilcisinin tıbbi müdahalenin konusu ve sonuçları hakkında bilgilendirilip aydınlatılmasının esas olduğu, verilen rızanın tıbbi müdahalenin gerektirdiği sürecin devamı olan ve zorunlu sayılabilecek rutin işlemleri de kapsadığı, tıbbi müdahalenin hasta tarafından verilen rızanın sınırları içerisinde olması gerektiği, hastaya tıbbi müdahalede bulunurken yapılan işlemin genişletilmesi gereği doğduğunda müdahale genişletilmediği takdirde hastanın bir organının kaybına veya fonksiyonunu ifa edemez hale gelmesine yol açabilecek tıbbi zaruret hâlinde rıza aranmaksızın tıbbi müdahale genişletilebileceğine yer verilmiştir. ${ }^{[17]}$

Hasta Hakları Yönetmeliği'nde hastanın kısıtlı olması durumunda vasisinden izin alınması gerektiği, vasisinin olmadığı veya hazır bulunamadığı veya hastanın ifade gücünün olmadığı hallerde bu şartın aranmayacağı, kanuni temsilcinin rızasının yeterli olduğu hallerde dahi, anlatılanları anlayabilecekleri ölçüde, küçük veya kısıtlı olan hastanın dinlenmesi suretiyle mümkün olduğu kadar bilgilendirme sürecine ve tedavisi ile ilgili alınacak kararlara katılımı sağlanması gerektiği yer almaktadır.

Benzer ibareye Bali Bildirgesi'nde de rastlanmaktadır. Bilinci kapalı veya iradesini ifade edebilme durumunda olmayan hastalarda hastanın bilgilendirilmiş onayı en uygun zamanda yasal temsilcisinden alınması gerektiği, yetkili yasal bir temsilcinin olmadığı ve acil tıbbi girişim gereken durumlarda daha önceden hastanın bu girişimi reddettiğini gösteren bir açıklaması yoksa hastanın onayı varsayılarak tıbbi girişim yapılabileceği belirtilmiştir. ${ }^{[16]}$

Yine Avrupa Hasta Haklarının Geliştirilmesi Bildirgesi olarak bilinen 1994 tarihli Amsterdam Bildirgesi'nde hastanın iradesini beyan etmesinin mümkün olmadığı 
ve acilen tıbbi girişim yapılması gereken durumlarda, daha önceden bu girişimi reddettiğini gösteren bir açıklaması yoksa hastanın onayı varsayılarak girişim yapılabileceği belirtilmektedir. Hastanın yasal temsilcisinin onayının gerektiği ve önerilen girişimin acil olduğu durumda eğer temsilcinin onayı zamanında alınamıyorsa tıbbi girişim yapılabileceği, yasal temsilcinin onayı gerektiği zaman hastaların (çocuk veya erişkin olsun) durumlarının izin verdiği ölçüde yine de karar alma sürecine dâhil edilmesi gerektiği, yasal temsilcinin onayı vermeyi reddettiği durumda, doktor veya diğer sağlık personelinin görüşü girişimin hastayı ilgilendirdiği yolunda ise, karar mahkemeye veya hakem heyeti benzeri merciye bırakılması gerektiği belirtilmektedir. Hastanın onay vermesinin mümkün olmadığı ve yasal temsilcisinin bulunmadığı veya bu amaçla seçilmediği bütün diğer durumlarda hastanın istekleri tahmin edilerek ve hesaba katılarak alternatif karar alma biçimi için uygun önlemler alınmalıdır. ${ }^{[21]}$

Anayasa Mahkemesi'nin verdiği kararda hukuken rızayı açılaması gereken kişinin kural olarak tıbbi uygulamaya maruz kalacak kişi olması gerektiği, reşit ve ayırt etme gücüne sahip hastanın kendisinin rıza açıklama ehliyetine sahip olduğu, ayırt etme gücüne sahip olmayanlar bakımından bu kişilerin vasilerinin rıza açıklama yetkilerinin bulunduğu belirtilmiştir. ${ }^{[23]}$

Avrupa İnsan Hakları Mahkemesi (AiHM); kişilerin fiziksel ve ruhsal bütünlüklerinin korunmasının, kendilerine uygulanan tedaviye dâhil olmaları, bu hususta rıza göstermelerinin ve maruz kaldıkları sağlık risklerini değerlendirmelerine yardımcı olan bilgilere erişimlerinin sözleşmenin 8. maddesi kapsamı içinde yer aldığını kabul etmektedir. ${ }^{[24]}$

Burada önemli bir durum kanuni temsilcisi tarafından rıza verilmeyen hallerde, müdahalede bulunmak tıbben gerekli ise, velayet ve vesayet altındaki hastaya tıbbi müdahalede bulunulabilmesi; Türk Medeni Kanununun 346. ve 487. maddeleri uyarınca mahkeme kararına bağlıdır. Söz konusu durumda yetkili mahkeme sulh hukuk mahkemesidir ve duruma göre birkaç günde karar verilebilmektedir. Amsterdam Bildirgesi'nde yer aldığı gibi hukuk ve sağlık düzenimizde hakem heyeti yer almamakta ancak bu düzenin uygulanmasının gerek hastalar gerek sağlık çalışanları açısından önemli bir sorunu çözeceği kanaati doğmaktadır.

Kanuna göre, akıl hastalığı, bir hastalık veya benzer nedenlerden dolayı, müdahaleye muvafakat etme yeteneği bulunmayan bir yetişkine, ancak temsilcisinin veya kanun tarafından belirlenen kişi veya makamın izni ile müdahalede bulunulabilir. İlgili kişi mümkün olduğu ölçüde izin verme sürecine katılacaktır. ${ }^{[25]}$
Doktrinde geciktirilmesinde tehlike bulunan durumlarda hekim hastanın rızasının olmadan acil bir müdahalede bulunsa hayat kurtarma ve tedavi amacı ile yaptığı için bu eylemler hukuka aykırı nitelik taşımayacağı belirtilmektedir. ${ }^{[13]}$

Tıbbi müdahaleden önce gerektiği şekilde bilgilendirerek rızasının alınmaması kişinin maddi ve manevi varlığını koruma hakkının ihlaline sebep olabileceği ve yapılan bilgilendirme ile tıbbi müdahale arasında hastanın sağlıklı bir kanaate varmasını sağlayacak kadar uygun bir zaman aralığı bırakılmış olmasına dair Anayasa Mahkemesi'nin kararı bulunmaktadır. ${ }^{[23]}$

Biyotıp Sözleşmesi'nde de sağlık alanında herhangi bir müdahale, ilgili kişinin bu müdahaleye özgürce ve bilgilendirilmiş bir şekilde muvafakat etmesinden sonra yapılabilir. Bu kişiye, önceden, müdahalenin amacı ve niteliği ile sonuçları ve tehlikeleri hakkında uygun bilgiler verilecektir. İlgili kişi, muvafakatini her zaman, serbestçe geri alabilir ibaresi bulunmaktadır. ${ }^{[25]}$

Tüm bu bilgiler ışığında kalça kırığı nedeniyle yapılacak ameliyatın onamının bizzat hasta tarafından verilmesi gerektiği, hasta ile iletişim kurulamadığı, hastanın akıl hastalığı veya kısıtlı olması durumunda yasal temsilcisi olan vasisinin onam vermesi gerektiği anlaşılmaktadır. Yasal temsilcisi yoksa eğer birinci derece yakınları ameliyatın yapılması konusunda hemfikir ise ameliyat birinci derece yakınlarının onayı ile yapılabilecekken, yakınları arasında fikir birliğinin olmaması halinde vasi tayini için sulh hukuk mahkemesine başvurularak mahkemeden vasi tayini talebinde bulunulabilir.

\section{Onam Formu}

Hastanın bilgilendirilmesi ve onamının alınması bir formu imzalatmaktan ötedir. Onam formunda herhangi bir şekil şartı bulunmamaktadır. ${ }^{[17]}$ Ancak yapılan bilgilendirmenin ve alınan rızanın ispatı açısından alınan aydınlatılmış onamın yazılı olması önem arz etmektedir. Tababet ve Şuabatı Sanatlarının Tarzı İcrasına Dair Kanun'da büyük cerrahi işlemler için rıza açıklamasının yazılı olması gerektiği ayrıca belirtilmektedir. ${ }^{[15]}$

Hasta Hakları Yönetmeliği'nde formdaki bilgilerin hastaya aktarılarak hastaya veya kanuni temsilcisine imzalatılacağı düzenlenmiştir. Formun iki nüsha olarak imza altına alınması gerektiği ve bir nüshanın hastanın dosyasına konulup diğerinin ise hastaya veya kanuni temsilcisine verilmesi gerektiği belirtilmektedir. ${ }^{[17]}$

Yine aynı yönetmelikte acil durumlarda tıbbi müdahalenin hasta tarafindan kabul edilmemesi durumunda, bu beyanın imzalı olarak alınacağı, hastanın veya yasal temsilcisinin imzadan imtina etmesi halinde durumun tutanak altına alınmasının gerekliliği üzerinde durulmuştur. Onam formunun bilgilendirmeyi yapan 
ve tıbbi müdahaleyi gerçekleştirecek sağlık meslek mensubu tarafından imzalanması gerektiği, verilen bilgilerin doğruluğundan ilgili sağlık meslek mensubu sorumlu olduğu ve arşiv mevzuatına uygun olarak muhafaza edilmesi gerektiğine de yer verilmiştir. ${ }^{[17]}$

Muvafakatname başlığı altında sunulan belgenin gerekli aydınlatmayı içermemesi ve sadece rıza mahiyetinde olmasından dolayı aydınlatılmış onam formu olarak kabul görmemektedir. ${ }^{[22]}$

Danıştay 15. dairesinin vermiş olduğu bir kararda hastanın bilgilendirilerek rızasının alındığına ilişkin aydınlatılmış onam belgesinin olmadığının görülmesine istinaden belirtilen yükümlülügün yerine getirilmemiş olmasının sağlık hizmetinin gerektiği gibi yürütülmediği ve hastada endişe ve üzüntüye yol açtı̆̆ına müteakip manevi tazminata hükmedilmesinin gerektiği belirtilmiştir. ${ }^{[26]}$

\section{TIBBi MÜDAHALENIN GENIŞLETILMESi}

Rızanın kapsamının genişletilmesi tanıya oranla daha farklı bir cerrahi girişimde bulunulması durumunda girişime son verilip rıza alınamayacağı için ilk verilen rızanın bu durumu kapsadığı kabul edilir. ${ }^{[13]}$ Kalça kırıklarında osteosentez planlanması ve ameliyat sırasında total veya parsiyel protez kullanılmasının gerekmesi bu duruma örnek olarak verilebilecektir.

\section{ileriye Dönük Beyan}

Daha önceden karar verme yetisi olan hastalar karar verme dönemlerinde ileriye dönük hasta talimatı olarak bilinen, kişinin ileride olası yapılacak müdahalelere önceden karar vererek yazılı hale getirdiği uygulamanın Türk hukuk sisteminde pratikte çok fazla yeri bulunmamaktadır.

Mevzuatta tıbbi müdahale sırasında isteğini açıklayabilecek durumda bulunmayan bir hastanın, tıbbî müdahale ile ilgili olarak önceden açıklamış olduğu istekleri göz önüne alınacağı, yeterliğin zaman zaman kaybedildiği tekrarlayıcı hastalıklarda, hastadan yeterliği olduğu dönemde onu kaybettiği dönemlere ilişkin yapılacak tıbbi müdahale için rıza vermesi istenebileceği belirtilmektedir. ${ }^{[17]}$

Müdahale sırasında isteğini açıklayabilecek bir durumda bulunmayan bir hastanın, tıbbî müdahale ile ilgili olarak önceden açıklamış olduğu istekler göz önüne alınacaktır. ${ }^{[25]}$

\section{Tedaviyi Reddetme}

Hasta tıbbi girişimi reddetme veya durdurma hakkına sahiptir. Reddedilen veya durdurulan tıbbi girişimin getireceği sonuçlar hastaya dikkatli bir şekilde açıklanmalıdır. ${ }^{[21]}$
Dünya Tabipler Birliği tarafından 1981 yılında yayınlanan Lizbon Hasta Hakları Bildirgesi'nde hastanın yeterli ölçüde bilgilendirildikten sonra önerilen tedaviyi kabul veya reddetme hakkına sahip olduğu bildirilmiştir. [27]

Diğer bir önemli düzenleme olan Bali Bildirgesi'nde; "Zihinsel yeterliliği olan erişkin bir hasta herhangi bir tanı veya tedaviye yönelik girişimi onaylama veya kabul etmeme hakkına sahiptir. Hastanın kendi kararını verebilmesi için gerekli şekilde bilgilendirmeye hakkı vardır. Hasta uygulanacak test veya tedavinin amacının ne olduğunu, bunun sonuçlarının ne olabileceğini, tedaviyi kabul etmeme durumunda olabilecekleri açık bir şekilde anlamalıdır" ifadelerine yer verilmiştir. ${ }^{[16]}$

Tedaviyi reddetme ile ilgili Hasta Hakları Yönetmeliğ̈'nde "Kanunen zorunlu olan haller dışında ve doğabilecek olumsuz sonuçların sorumluluğu hastaya ait olmak üzere; hasta kendisine uygulanması planlanan veya uygulanmakta olan tedaviyi reddetmek veya durdurulmasını istemek hakkına sahiptir. Bu halde, tedavinin uygulanmamasından doğacak sonuçların hastaya veya kanuni temsilcilerine veyahut yakınlarına anlatılması ve bunu gösteren yazılı belge alınması gerekir. Bu hakkın kullanılması, hastanın sağlık kuruluşuna tekrar müracaatında hasta aleyhine kullanılamaz." olarak beyan edilmiştir. ${ }^{[17]}$

Kalça kırığı nedeniyle başvuran ve tıbbi açıdan ameliyatın gerekli olduğu durumda hastanın bunu reddetme hakkı bulunmaktadır. Bu durumda ilgili yönetmelik doğrultusunda doğabilecek olumsuzluklardan hastanın kendisi sorumlu olmaktadır. Elbette olası olumsuzlukları hastaya anlatmak yani bu konuda da bilgilendirmede bulunmak gereklidir.

\section{SON SÖZ}

Mevzuattaki düzenlemelerin hepsi göz önünde bulundurulduğunda kalça kırığı tanısıyla hastaneye başvuran hastaya yapılacak olan tıbbi işlemin olası riskleri, tedavi alternatifleri ve riskleri, tedavi olunmadığı durumda yaşanabilecek problemler bizzat hastanın kendisine anlatılmalı ve onayının alınması gerekmektedir.

Hastanın kısıtlı olması, ayırt etme gücüne sahip olmaması veya iletişim kurulmasında zihinsel fonksiyonlara bağlı engel durumun olması halinde yasal temsilcisine bilgilendirme yapılarak onayı alınmalıdır. Yasal temsilcisinin olmaması halinde birinci derece yakınlarının tümünün onayı yeterli olabilecekken, yakınları arasında fikir birliği olmaması halinde hastanın yerleşim yeri sulh hukuk mahkemesinden vasi tayini istenebilecektir. Vasi tayini talebinde bulunurken hastanın durumunu belirten ve ameliyatın gerekliliğini anlatan bir yazı, hastanın kısıtlı olduğunu, hastanın ifade gücünün olmadığı veya anlatılanları anlayabilecek durumda 
olmadığını gösteren tercihen bir psikiyatri veya nöroloji uzmanından yazı ve vasi olabilecek yakınları ile başvuruda bulunulabilecektir. Durumun ivedilikle olması açısından mahkemece vasi tayini sıklıkla birkaç gün içinde yapılabilmektedir. Dolayısıyla, kalça kırı̆ı̆ hastasına ameliyat hazırlığı yapıldığında tıpkı konsültasyon yapıldığı gibi vasi tayini de eş zamanlı olarak yapılabilecek, bu da zamandan tasarruf sağlayabilecektir.

Hasta yakınlarına ulaşılamaması durumunda hastanın daha önceden bu konuda aksine verilmiş bir beyanı bulunmuyorsa hekim bir başka ortopedi ve travmatoloji uzmanı ile durumu paylaşarak hasta için olabilecek en iyi seçeneği uygulamalıdır.

Unutulmamalıdır ki, bilgilendirilerek onayı alınmadan yapılan bir tıbbi müdahale tıbbi olarak geçerli olabilecekken hukuki açıdan geçersiz bir işlem olarak kabul edilmektedir.

\section{KAYNAKLAR}

1. WHO. Psychogeriatrics. Report of a WHO scientific group. World Health Organ Tech Rep Ser 1972;507:1-48. https:// pubmed.ncbi.nlm.nih.gov/4627568/

2. WHO. The uses of epidemiology in the study of the elderly. Report of a WHO Scientific Group on the Epidemiology of Aging. World Health Organ Tech Rep Ser 1984;706:1-84. https://pubmed.ncbi.nlm.nih.gov/6437089/

3. WHO. Active Ageing: A Policy Framework, 2002. https://extranet.who.int/agefriendlyworld/wp-content/ uploads/2014/06/WHO-Active-Ageing-Framework.pdf

4. Türkiye İstatistik Kurumu Hayat Tabloları, 2017-2019. TUiK Haber Bülteni Sayı: 33711. https://www.tuik.gov.tr/

5. Türkiye İstatistik Kurumu İstatistiklerle Yaşlılar, 2019. TUiK Haber Bülteni Sayı: 33712. https://www.tuik.gov.tr/

6. Çakmur H, Erem T, Koç M, Ertekin V, Karslıoğlu I, Kırağı D. CA tanısı alan Geriatrik olguların demografik incelemesi. Türk Geriatri Derg 2000;3(1):11-4. http://geriatri.dergisi.org/ uploads/pdf/pdf_TJG_30.pdf

7. Kalish B, Gillham J, Unwin K. Delirium in Older Persons: Evaluation and Management. Am Fam Physician 2014;90(3):150-8. https://www.aafp.org/afp/2014/0801/ p150.html

8. Yüksel S, Çağlar S, Alagöz E, Gültekin Z, Güleç A. Yaşlı Kalça Kırıklarında Kırık Tipinin Mortalite Üzerine Etkisi. Türkiye Klinikleri J Orthop Traumatol - Special Topics 2016;9(2):2632. https://www.turkiyeklinikleri.com/article/tr-yasli-kalcakiriklarinda-kirik-tipinin-mortalite-uzerine-etkisi-74770.html

9. Veatch RM. Bioetiğin Temelleri, 2. Basım. Çev. Güven T. US: Prentice Hall; 2010. s.47

10. T.C. Anayasası, m: 17. Kanun Numarası 2709. Kabul Tarihi: 18/10/1982 Yayımlandığı Resmî Gazete. Tarih: 9/11/1982. https://www.mevzuat.gov.tr/
11. Avrupa İnsan Hakları Sözleşmesi (11. ve 14. Protokoller ile değiştirilen metin). Avrupa Antlaşmaları Serisi, No: 5. https:// www.danistay.gov.tr/upload/avrupainsanhaklarisozlesmesi. pdf

12. T.C. Yargıtay 15. Hukuk Dairesi Esas No: $2017 / 2329$, Karar No: 2019 / 2441 Karar Tarihi 22.05.2019. https://www. yargitay.gov.tr/

13. Helvacı S, Erlüle F. Medeni Hukuk, 5. Basım. İstanbul: Legal Yayıncılık; 2018.

14. Türk Medeni Kanunu. madde 10 Kanun Numarası: 4721 Kabul Tarihi: 22/11/2001. Yayımlandığı Resmî Gazete. Tarih: 8/12/2001 Sayı: 24607. https://www.mevzuat.gov.tr/

15. 1219 sayılı Tababet ve Şuabatı Sanatlarının Tarzı İcrasına Dair Kanun. https://www.mevzuat.gov.tr/

16. Dünya Tabipler Birliği. Bali Bildirgesi. Endonezya, 1995. https://sbu.saglik.gov.tr/hastahaklari/bali.htm

17. Hasta Hakları Yönetmeliği. Resmî Gazete Tarihi: 01.08.1998. Resmî Gazete Sayısı: 23420. http://etikkurul.kocaeli.edu.tr/ dosyalar/1998-hasta-haklari-yonetmeligi.pdf

18. Türk Tabipleri Birliği. Hekimlik Meslek Etik Kuralları, 2012. https://www.ttb.org.tr/kutuphane/h_etikkural.pdf

19. T. C. Yargitay 13. Hukuk Dairesi Esas No: 2013/3720, Karar No: 2013 / 32218 Karar Tarihi 23.12.2013. https://www. yargitay.gov.tr/

20. Dinç M, editör. Anayasa Mahkemesi Kararları. Gecekuşu Ş. / Türkiye (k.k.), B. No: 28870/05, 25/5/2010; Trocellier v. / Fransa. Terazi Hukuk Derg 2019;14(154):1278-98. https:// jurix.com.tr/article/18996

21. Avrupa Hasta Haklarının Geliştirilmesi Bildirgesi 28-30 Mart 1994 (Amsterdam Bildirgesi). https://sbu.saglik.gov.tr/ hastahaklari/amsterdam.htm

22. T.C. Yargitay 13. Hukuk Dairesi Esas No: 2016/25663, Karar No: 2018 / 7615 Karar Tarihi 04.07.2018. https://www. yargitay.gov.tr/

23. Anayasa Mahkemesinin $11 / 10 / 2018$ tarihli ve $2015 / 97$ sayılı kararı (bireysel Başvuru). https://www.anayasa.gov.tr/

24. Dinç M, editör. Anayasa Mahkemesi Kararları. Karakoca i, Karakoca H. Trocellier v. / Fransa (k.k.), B. No: 75725/01, 5/10/2006; / Türkiye (k.k.), B. No: 46156/11, 21/5/2013. Terazi Hukuk Derg 2019;14(154):1278-98. https://jurix. com.tr/article/18996

25. Biyoloji ve Tıbbın Uygulanması Bakımından İnsan Haysiyetinin Korunması Sözleşmesi: İnsan Hakları ve Biyotıp Sözleşmesi Kanun no: 5013. Kabul Tarihi 03.12.2003. https://www. mevzuat.gov.tr/

26. T.C. Danıştay 15. Dairesi Esas No: 2014/3146, Karar No: 2019 / 290 Karar Tarihi 05.02.2019. https://www.danistay. gov.tr/

27. Dünya Tabipler Birliği. Lizbon Hasta Hakları Bildirgesi, 1981. http://www.istanbulsaglik.gov.tr/w/hashak/belge/mevzuat/ lizbon_bildirgesi1981.pdf 